\section{Sense-Organs in Malacobdella}

WHILE examining living specimens of Malacobdella grossa, Müll., under a binocular dissecting microscope (the specimen being extended under a glass slide in sea-water in the usual manner), I noticed a pair of minute structures on the head, which, so far as I can trace, do not correspond to anything previously described in this species. Fig. 1, drawn from a living specimen, shows these organs anterior to the cerebral ganglia, which send a small nerve in their direction. They have the appearance of small pits on the dorsal surface, suggestive of sense-organs. They are un. pigmented.

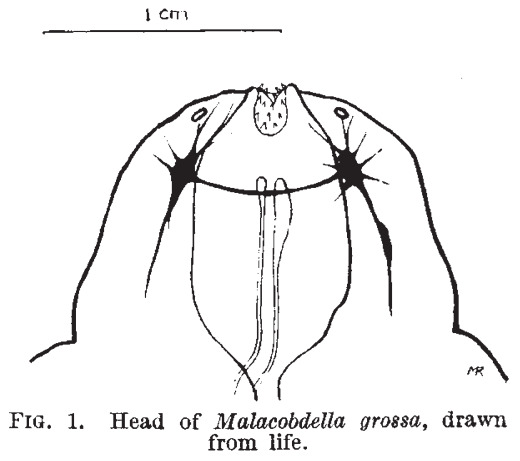

I have examined serial sections of a specimen in which these 'organs' were seen during life, but so far have failed to find them; they have, however, been observed on several living specimens. They are more conspicuous in large specimens. If they are sense-organs, the fact is of some interest, since, except for the neuro-epithelial cells, Malacobdella has been supposed to be entirely devoid of these ${ }^{1,2}$. A cephalic slit is present in most Nemerteans in a variety of forms ; and a reduced cephalic slit might well present the appearance shown. In some Nemerteans the cephalic slits are mere superficial depressions ; and if, as a result of the semi-parasitic habit, these became reduced in Malacobdella to a vestige, they might be difficult to trace in preserved specimens, though visible during life.

The specimens were obtained in Pholas from the collecting ground known as 'Black Rocks', on the Anglesey shore at the eastern end of the Menai Straits. I can confirm the remarks of Gering ${ }^{3}$ that the dimensions of $M$. grossa usually given are an understatement. Living specimens measuring $45 \mathrm{~mm}$. long in a state of moderate extension have been obtained here, whereas the largest Kiel specimen observed by Riepen was $22 \mathrm{~mm}$. in length, and the largest Iceland specimen $30 \mathrm{~mm}$. Blanchard ${ }^{4}$ records a maximum length of $40 \mathrm{~mm}$. The frequency here is also high, practically 100 per cent of specimens of Pholas being infected, as compared with less than 60 per cent infection recorded by Riepen for the host Cyprina at Kiel.

My thanks are due to Dr. Stiasny Wijnhoff for advice and assistance with the literature.

Zoology Department,

University College,

Bangor.

March 14.

' Riepen, Z. Wiss. Zool., 143 ; 1933.

Gurger, "Fauna und Flora des Golf

Gering, Z. Wiss. Zool.,97 ; ' (S11. 1845.

\section{Discriminative Ability of a Parasitoid}

IT has recently been demonstrated ${ }^{\mathbf{1}}$ that Tricho. gramma evanescens and certain other parasitoids are able to distinguish between healthy hosts and those already parasitised. Hearing cannot enter; sight and touch have been ruled out; and it appears that the sense used is that of smell.

The discriminative ability is much finer than was supposed, as shown by the following experiment. A Trichogramma female was allowed to walk upon and to examine a number of host eggs, but not to parasitise them. The parasite was then removed and an equal number of clean hosts placed alternately among the others. A second parasite now introduced avoided the hosts that had been visited by the first, as though they had already been parasitised. The experiment has been performed several times, and there can be no doubt that Trichogramma females are able to distinguish clean hosts from those that have previously been merely walked upon by another female of their species, and that they avoid attacking the latter. They seem also to be able to distinguish hosts on which they themselves have walked from those which have been visited by another individual.

One of us (J. L.) is now working on the application of this result to the spatial distribution of Trichogramma; and has evidence that the parasites are aware when they are moving over a surface pre. viously walked upon by another parasite.

This result renders intelligible a previous observa. tion $^{1}$ on Collyria calcitrator and Ibalia leucospoides. Both of these parasitoids attack hosts which are buried in plant tissues and are therefore not available for examination. Yet they tend to avoid superparasitism. Possibly in these cases, too, the parasites are able to detect, on the surface of the wheat or of the wood, chemical traces indicating that another of their species has been there before them.

George Salt.

J. LAING.

Sub-Department of

Experimental Zoology, Cambridge.

${ }^{1}$ Salt, G., Proc. Roy. Soc., B, 114, 455; 1934.

\section{Apus cancriformis in Great Britain}

Apus cancriformis has been so rarely recorded in Great Britain that it is of interest to report its occurrence in 1934. Some dried mud was collected from a pond in the New Forest district for the purpose of rearing Chirocephalus diaphanus, which was known to occur there. Distilled water was added to the mud on August 9, 1934, and larvæ were first noticed on August 12. These larvæ proved, on examination, to be those of Apus cancriformis, and not of the expected Chirocephalus. Development proceeded, but many died. One individual measuring about $6 \mathrm{~mm}$. across the carapace and $12 \mathrm{~mm}$. from the anterior margin of the head to the base of the caudal furca was preserved on September 29. Another was exhibited alive at the Linnean Society's reception in October last.

A. D. Hobson. Joseph OMER-CoOper.

Department of Zoology,

Armstrong College,

Newcastle-upon-Tyne. March 22. 